\title{
Emerging statistics on the Epidemiology of COVID-19: Making prevention in pregnancy less grievous than the disease
}

\author{
Imaralu JO \\ Department of Obstetrics and Gynecology, Benjamin Carson School of Medicine, Babcock University, \\ llishan-Remo, Nigeria.
}

\begin{abstract}
Background: Pregnant women are a vulnerable group to the COVID-19 infection; although it is expected that adaptive changes of pregnancy put them at increased risk of adverse outcome from any respiratory tract infection, interventions for the COVID-19 may put them in more danger. Nigeria is one of the leading countries with very poor maternal mortality indices and many other sub-Saharan African nations are in the same boat. Contingency plans need to be put in place to prevent precipitous deterioration in mortality rates occasioned by the dreaded SARSCov-2 pandemic. This mini-review of literature and WHO global statistics is aimed to determine the trends in COVID-19 transmission and mortality rates to provide evidence-based information that may enable governments to tailor their interventions to the peculiar needs, of sub-Saharan African populations.

Main body: Emerging epidemiological trends on transmission and mortality within Africa and the worst affected regions of the world suggests better outcomes of this infection in sub-Saharan Africa, than in other regions of the world. Also, present data allude to similar outcomes between pregnant and non-pregnant women. The present containment measures of isolation and quarantine, including city-wide lockdowns, may put pregnant women at higher risk of death from other causes rather than COVID-19. The danger posed, is the limitation of access to emergency obstetric care services when pregnant women develop non-COVID-19 complications of pregnancy. Conclusion: The COVID-19 pandemic has lower local transmission rates and fatality in Africa, the region where the virus arrived last. While special efforts should be geared at shielding the elderly and infirm from contracting the infection, preventive measures in pregnant women must allow for access to emergency obstetric care to forestall iatrogenic adverse maternal outcomes.
\end{abstract}

Keywords: Adverse outcomes, Africa, coronavirus, infectious disease, lockdown, lungs, safe motherhood.

\section{Background}

Nigeria, with a population of over 200 million people can be considered as one of the world's most populous countries, with one of the poorest maternal and perinatal mortality indices. Many of the sub-Saharan African nations are in the same boat. The maternal mortality ratio in Nigeria as of 2015 was over 800 per 100,000 live births (1). Contingency plans need to be put in place to prevent a precipitous deterioration in this rate as a result of the ravaging COVID-19 or its preventive interventions. Pregnant women and children fall amongst the most vulnerable population groups especially at this time of the COVID-19 pandemic, thus special care must be taken, in considering, the social, health, and economic impacts of the pandemic and interventions undertaken to stem the spread of the virus. The WHO director-general mentioned in a recent media briefing that ensuring free access to essential health products is vital to saving lives and curbing the social and economic impacts of the pandemic (2).

The emanating daily statistics regarding the high infective property of the new coronavirus strain COVID-19, especially its rapid transmission across the globe and the nature of the consequent deaths sweeping across countries, calls for concerted efforts towards curbing local transmission within territories already colonized. The COVID-19 virus infection presently has no known cure and presently there is no evidence to recommend any specific anti-COVID-19 treatment for patients confirmed to have this disease (3). 
The news of very high case fatality rates obtained from industrialized nations with stronger health systems and sophisticated infrastructure is a source for concern (4). The facilities and equipment in industrialized nations that have hitherto supplied help to LMICs are overstretched and not even enough for the present challenges experienced by these nations.

As of $4^{\text {th }}$ April 2020, 1,051, 635 confirmed cases of COVID-19 positive persons and 56,985 deaths globally, had been reported to the WHO (4). There were fears about how this virus would impact African Nations considering the prevalent weak health systems with suboptimal infrastructural back up (5). The recent mass exodus of healthcare workers to Europe and the Americas together with continued security threats from terrorism and violent crimes make this new lethal viral threat a source of concern for governments in this subregion. The dwindling national income from the drop in crude oil price makes this period a precarious one especially for Nigeria $(6,7)$.

The recently observed transmission, morbidity, and mortality-trends across the globe, however, appear to be in discordance with the predictions of doom for the sub-Saharan African people. The present statistics which put Africa at the least affected region (as of $4^{\text {th }}$ April 2020) with 5,446 cases and 183 deaths raises a lot of questions considering the peculiar social and infrastructural vulnerability of this region (4). The aged, individuals with other co-morbid chronic diseases like lung, kidney, heart disease, and diabetes mellitus especially diseases affecting ACE-2 signaling are at increased risk of infection with and adverse outcome from the COVID-19 (8). There has also not been any clear difference in the outcome, between pregnant and non-pregnant women infected with the COVID-19 virus. Besides, there is presently no clear evidence of mother-to-child transmission or perinatal mortality or morbidity immediately traceable to the COVID-19 virus (3).

The majority of the Nigerian population are young and ranked as being among the extremely poor globally (9), thus the prospects of stocking up supplies for a prolonged lockdown look grim. A large proportion of the female population are of child-bearing age, the nation also has a high fertility rate, and thus a significant pregnant population would be expected at this time (10). Presently, over $60 \%$ of the deliveries in Ogun state (one of the 3 states presently under lockdown) take place outside a hospital-setting mostly attended by traditional (or spiritual) birth attendants, whom the WHO does not recognize as skilled (11).
The restriction of movement is likely to affect the referral chain and further limit access to skilled healthcare especially when complications do happen (12).

Based on the foregoing, the social and health implications of the intervention measures to curtail the spread of the COVID-19 virus need to be considered and interventions carefully planned such that hunger, other diseases, and anarchy do not cause mass mortality where the COVID-19 virus may have spared.

This mini-review of literature and current WHO statistics is aimed to determine the trends in COVID-19 transmission and mortality rates to provide evidence-based information that would help safely tailor interventions to peculiar needs, especially the sub-Saharan African populations.

\section{Main Text}

The COVID-19 virus and previous coronavirus outbreaks

Coronaviruses are groups of enveloped nonsegmented RNA viruses of the Coronaviridae family and the order Nidovirales. They are transmissible between humans and animals and cause mild flu-like respiratory tract infections (13). Two severe epidemics have however occurred; the severe acute respiratory syndrome coronavirus (SARS-CoV) with a mortality rate of $10 \%$ and the Middle East respiratory syndrome coronavirus (MERS-CoV) with a mortality rate of $37 \%(14,15)$.

COVID-19 is a respiratory tract infection caused by a new strain of coronavirus, SARS-CoV-2, that was first recognized in Wuhan, China, in December 2019. Genetic sequencing of this virus in January 2020 suggests that SARSCoV-2 is also a beta-coronavirus closely related to SARS-CoV (16).

The earliest symptoms of COVID-19 include fever, cough, myalgia, and fatigue. Other less common symptoms include sputum production, headache, hemoptysis, and diarrhea. Dyspnoea develops when viral pneumonia gets worse and may herald acute respiratory distress syndrome and cardiac injury. Superimposed bacterial infections are also known to worsen the illness. The consequent Acute Respiratory Distress Syndrome (ARDS) and multi-organ damage results in the Intensive Care Unit (ICU) admissions. Presently, the case fatality rate is about $2 \%$, but values as high as $15 \%$ have been observed among the aged and sick (17).

\section{Pathogenesis and clinical manifestations of the COVID-19 infection}


The knowledge of this new coronavirus infection is rapidly evolving by the day; an earlier report of the first 41 cases of COVID-19 suggests that most of the initial test positive patients may have been victims of viral contaminated food from the Huanan seafood market in Wuhan, mainland China (8). While most people with COVID-19 develop a mild or uncomplicated illness, averagely $14 \%$ develop severe disease requiring hospitalization, oxygen support, and ICU care $(8,16)$. Severe COVID-19 infection can be complicated by (ARDS), sepsis and septic shock, multi-organ failure, including acute kidney injury and cardiac injury (18). Older age and co-morbid diseases have been reported as risk factors for death $(17,19)$. The median duration of viral detection is 20 days while the longest duration of viral shedding observed in survivors was 37 days, the SARS-CoV-2, RNA was however still detectable in the body fluids of patients who died up to the time of death (19).

Coronavirus infections have similar antibody profiles to other viral infections which produce IgM and IgG immunoglobulins. The SARSspecific IgM antibodies can be present in the bloodstream for up 12 weeks while the IgG antibodies can last for a long time, indicating that IgG antibodies may play a protective role, thus increasing prospects for vaccine-cure. ARDS is the common immune-pathological pathway for SARS-CoV-2, SARS-CoV, and MERS-CoV infections (20). One of the main mechanisms for ARDS of the COVID-19 is the cytokine storm, which has been described as the tumultuous uncontrolled systemic inflammatory response resulting from the release of large amounts of pro-inflammatory cytokines (IFN- $\alpha$, IFN- $\gamma$, IL-1 $\beta$, IL-6, IL-12, IL18, IL-33, TNF- $\alpha$, TGF $\beta$ ) and chemokines (CCL2, CCL3, CCL5, CXCL8, CXCL9, CXCL10) by immune effector cells (21). The cytokine storm triggers a violent attack by the immune system to the body, resulting in ARDS and multiple organ failure, especially affecting organs like the lungs, the kidney, heart, and the liver. Genetic differences may contribute to individual variations in the immunological response to this virus. Thus, when a protective immune response is impaired, the virus will propagate and massive destruction of the affected tissues will then begin, especially in organs that have high ACE-2 expressions, such as intestine and kidney. This damage is largely mediated by pro-inflammatory macrophages and granulocytes (20).

\section{Comparison of transmission rates and mortalities: African region versus others}

As of $31^{\text {st }}$ March 2020, there were a total of 750,178 confirmed cases of COVID-19 infected individuals globally, while 36,398 deaths had occurred [Table 1]. The region with the highest number of confirmed cases was Europe, which also had the greatest number of deaths. Chinawhere the principal case was first reported had less than half the total number of deaths in Europe and about $1 / 8$ the total number of confirmed cases.

Sub Saharan African region (AFRO) had the least number of confirmed cases of COVID-19 and had also recorded a total of 77 deaths and only one occurred in Nigeria. A closer look at the intervals from the identification of the principal case in Wuhan, China; to the date of confirmation of regional index case (P-I interval), reveals that AFRO had the longest interval (87 days), i.e., virus arrived Africa last. Although Southeast Asia had the shortest P-I interval (44 days because Thailand was the first country to import the virus from China), this region had 4,215 confirmed cases and 166 deaths, which were among the lowest, across the $\mathrm{WHO}$ regions of the world.

Table 1: Principal case (i.e. the index case in Wuhan, China, reported $1^{\text {st }}$ December 2019) to confirmed regional index case interval, incidence, and mortality of COVID-19, by WHO regions [as of $31^{\text {st }}$ March 2020]

\begin{tabular}{|c|c|c|c|c|}
\hline WHO region & $\begin{array}{l}\text { Date of confirmed } \\
\text { regional index } \\
\text { case[Place] }\end{array}$ & $\begin{array}{l}\text { Principal- index } \\
\text { case interval (P. } \\
\text { I) interval }\end{array}$ & $\begin{array}{c}\text { No. of } \\
\text { confirmed } \\
\text { cases (22) }\end{array}$ & $\begin{array}{c}\text { No. of } \\
\text { confirmed } \\
\text { deaths }(22)\end{array}$ \\
\hline $\begin{array}{ll}\text { Western } & \text { Pacific } \\
\text { Region } & \\
\end{array}$ & $\begin{array}{c}1^{\text {st }} \text { Dec } 2019 \text { Principal } \\
\text { case }(8)\end{array}$ & - & 104,868 & 3,671 \\
\hline $\begin{array}{l}\text { Western pacific } \\
\text { outside China }\end{array}$ & $\begin{array}{c}15^{\text {th }} \text { January (23) } \\
\text { [Japan] }\end{array}$ & 46 days & a22,323 & b357 \\
\hline Southeast Asia & $\begin{array}{l}13^{\text {th }} \text { January (23) } \\
\text { [Thailand] }\end{array}$ & 44 days & 4,215 & 166 \\
\hline European region & $\begin{array}{c}25^{\text {th }} \text { January (24) } \\
\text { [France] }\end{array}$ & 56 days & 423,946 & 26,694 \\
\hline $\begin{array}{l}\text { Region of the } \\
\text { Americas }\end{array}$ & $\begin{array}{l}23^{\text {rd }} \text { January (25) } \\
\text { [USA] }\end{array}$ & 54 days & 163,014 & 2,836 \\
\hline $\begin{array}{l}\text { Eastern } \\
\text { Mediterranean } \\
\text { region }\end{array}$ & $\begin{array}{c}29^{\text {th }} \text { January (26) } \\
\text { [UAE] }\end{array}$ & 60 days & 50,349 & 2,954 \\
\hline Africa region & $26^{\text {th }}$ February (27) & 87 days & 3,786 & 77 \\
\hline
\end{tabular}




\begin{tabular}{lccc}
\hline & [Algeria] & & \\
\hline Total (all regions) & 750,178 & 36,398 \\
\hline & $\begin{array}{l}\mathrm{a}=\text { Not included in the calculation of the total, number of confirmed cases } \\
\mathrm{b}=\text { Not included in the calculation of the total number of confirmed deaths }\end{array}$
\end{tabular}

The summary of the WHO data presented in table 2, shows that while the European (EURO) and the Eastern Mediterranean (EMRO) regions had the highest Case Fatality Rates [CFR] $(6.2 \%$ and $5.9 \%$ respectively $)$ the disease appeared to be less fatal in the
Americas (AMRO), Africa and the other countries of the Western Pacific region apart from China. Nigeria had a CFR of $<1 \%$, as of $31^{\text {st }}$ March 2020 (28). Southeast Asia had case fatality rates similar to that of the Western Pacific region.

Table 2: Case fatality rates, by WHO regions, as of $31^{\text {st }}$ March 2019.

\begin{tabular}{lccc}
\hline \multicolumn{1}{c}{ WHO region } & $\begin{array}{c}\text { Confirmed } \\
\text { cases }(22)\end{array}$ & $\begin{array}{c}\text { Confirmed } \\
\text { deaths (22) }\end{array}$ & CFR (\%) \\
\hline Western Pacific Region & 104,868 & 3,671 & 3.5 \\
Western pacific outside China & 22,323 & 357 & 1.6 \\
Southeast Asia & 4,215 & 166 & 3.9 \\
European region & 423,946 & 26,694 & 6.2 \\
Region of the Americas & 163,014 & 2,836 & 1.7 \\
Eastern Mediterranean region & 50,349 & 2,954 & 5.9 \\
Africa region & 3,786 & 77 & 2.03 \\
\hline
\end{tabular}

The interval from the regional first confirmed case (index case) to first confirmed mortality was also examined to determine possible reasons for the differences in mortality trends. It is important to note from WHO statistics in table 3 that at the time of first mortality, all the regions of the world had established local transmission, and all mortalities occurred in intervals well above the earlier reported incubation period of 2-14 days for the new
SARS-Cov-2 virus (16). The occurrence of Africa's first mortality in Algeria after just 15 days of confirmed index cases suggests that the individual may have had a recent travel history to one of the very high-risk affected countries. It can be observed that the region of the Americas (40 days) and the Western Pacific (41 days) had the longest interval from the first confirmed case to the occurrence of the first confirmed death.

Table 3: Index case to first mortality, Interval by WHO regions

\begin{tabular}{|c|c|c|c|c|}
\hline WHO region & $\begin{array}{c}\text { Date of the } \\
\text { confirmed } \\
\text { regional index } \\
\text { case }\end{array}$ & $\begin{array}{l}\text { Date of first } \\
\text { confirmed } \\
\text { mortality }\end{array}$ & $\begin{array}{c}\text { Index case } \\
\text {-Mortality } \\
\text { (I-M) } \\
\text { interval }\end{array}$ & $\begin{array}{c}\text { Transmission } \\
\text { status at the } \\
\text { time of first } \\
\text { mortality }\end{array}$ \\
\hline $\begin{array}{l}\text { Western Pacific } \\
\text { Region }\end{array}$ & $\begin{array}{c}1^{\text {st }} \text { Dec } 2019 \\
\text { Principal case }(8)\end{array}$ & $\begin{array}{c}\operatorname{Jan} 11,2020 \\
(29)\end{array}$ & 41 days & $\begin{array}{c}\text { Local } \\
\text { transmission }\end{array}$ \\
\hline $\begin{array}{l}\text { Western pacific } \\
\text { outside China }\end{array}$ & $\begin{array}{c}15^{\text {th }} \text { January (23) } \\
\text { [Japan] }\end{array}$ & $\begin{array}{c}2^{\text {nd }} \text { February } \\
\text { (30) [Philippines] }\end{array}$ & 18 days & $\begin{array}{c}\text { Local } \\
\text { transmission }\end{array}$ \\
\hline Southeast Asia & $\begin{array}{c}13^{\text {th }} \text { January (23) } \\
\text { [Thailand] }\end{array}$ & $\begin{array}{l}2^{\text {nd }} \text { March (31) } \\
\text { [Thailand] }\end{array}$ & 20 days & $\begin{array}{c}\text { Local } \\
\text { transmission }\end{array}$ \\
\hline European region & $\begin{array}{c}25^{\text {th }} \text { January (24) } \\
\text { [France] }\end{array}$ & $\begin{array}{l}16^{\text {th }} \text { February } \\
\text { (32) [France] }\end{array}$ & 22 days & $\begin{array}{c}\text { Local } \\
\text { transmission }\end{array}$ \\
\hline $\begin{array}{l}\text { Region of the } \\
\text { Americas }\end{array}$ & $\begin{array}{c}23^{\text {rd }} \text { January (25) } \\
\text { [USA] }\end{array}$ & $\begin{array}{l}3^{\text {rd }} \text { March (33) } \\
\text { [USA] }\end{array}$ & 40 days & $\begin{array}{c}\text { Local } \\
\text { transmission }\end{array}$ \\
\hline $\begin{array}{l}\text { Eastern } \\
\text { Mediterranean region }\end{array}$ & $\begin{array}{l}2^{\text {th }} \text { January (26) } \\
\text { [UAE] }\end{array}$ & $\begin{array}{c}20^{\text {th }} \text { February } \\
\text { (34) [Iran] }\end{array}$ & 22 days & $\begin{array}{c}\text { Under } \\
\text { investigation }\end{array}$ \\
\hline Africa region & $\begin{array}{l}26^{\text {th }} \text { February } \\
\text { (27) [Algeria] }\end{array}$ & $\begin{array}{l}12^{\text {th }} \text { March (35) } \\
\text { [Algeria] }\end{array}$ & ys & $\begin{array}{c}\text { Local } \\
\text { transmission }\end{array}$ \\
\hline
\end{tabular}

NB: Index case was first mortality only in the Republic of Iran

The rate of local transmission was examined as highlighted in table 4 and found to be highest in the EURO and region of the Americas $(6,423.4$ confirmed cases per day and 2,397.3 confirmed cases per day respectively). This rate was lowest for the South East Asia region SEARO (54 confirmed cases per day), a finding which could explain the low incidence rates observed in that region as of $31^{\text {st }}$ March. Africa had the lowest local transmission rate despite the late 
international border closures (with a risk of multiple international entries from high-risk countries) and subsequent transmission in geometric proportions. Algeria was the first
African country to close her land borders and suspend air and maritime transport on $17^{\text {th }}$ March 2020, after haven recorded 49 cases out of which 3 had died $(36,37)$.

Table 4: Rate of Local transmission [number of cases per day] from index case to $31^{\text {st }}$ March 2020

\begin{tabular}{|l|c|c|c|c|}
\hline \multicolumn{1}{|c|}{ WHO region } & $\begin{array}{c}\text { Date of the first } \\
\text { regional } \\
\text { confirmed case }\end{array}$ & $\begin{array}{c}\text { No. of days } \\
\text { from Index case } \\
\text { to } \mathbf{3 1}^{\text {st }} \text { March }\end{array}$ & $\begin{array}{c}\text { No. of } \\
\text { Confirmed } \\
\text { cases (22) }\end{array}$ & $\begin{array}{c}\text { Rate of local } \\
\text { transmission } \\
\text { (cases per day) }\end{array}$ \\
\hline Western Pacific Region & $\begin{array}{c}1^{\text {st }} \text { Dec } 2019 \\
\text { Principal case (8) }\end{array}$ & 122 & 104,868 & 859.6 \\
\hline $\begin{array}{l}\text { Western pacific outside } \\
\text { China }\end{array}$ & $\begin{array}{c}15^{\text {th }} \text { January (23) } \\
{[\text { Japan] }}\end{array}$ & 76 & 22,323 & 293.7 \\
\hline Southeast Asia & $\begin{array}{c}13^{\text {th }} \text { January (23) } \\
{[\text { Thailand] }}\end{array}$ & 78 & 4,215 & 54 \\
\hline European region & $\begin{array}{c}25^{\text {th }} \text { January (24) } \\
{[\text { France] }}\end{array}$ & 66 & 423,946 & $6,423.4$ \\
\hline Region of the Americas & $\begin{array}{c}23^{\text {rd }} \text { January (25) } \\
{[\text { USA] }}\end{array}$ & 68 & 163,014 & $2,397.3$ \\
\hline $\begin{array}{l}\text { Eastern Mediterranean } \\
\text { region }\end{array}$ & $\begin{array}{c}29^{\text {th }} \text { January (26) } \\
{[U A E]}\end{array}$ & 62 & 50,349 & 812.1 \\
\hline Africa region & $\begin{array}{c}26^{\text {th }} \text { February (27) } \\
{[\text { Algeria] }}\end{array}$ & 34 & 3,786 & 111.35 \\
\hline
\end{tabular}

Summary of the COVID-19 statistics as of 31 $1^{\text {st }}$ March 2020

1. Africa has the lowest number of reported confirmed cases of COVID-19 infections

2. Africa has the lowest number of reported COVID-19 deaths

3. Europe and Eastern Mediterranean regions have the highest CFR, while Southeast Asia had CFR similar to Western pacific, lower CFR were recorded by the Americas and African region

4. The Americas and Western Pacific regions had the longest interval from the first confirmed case to first reported mortality

5. Local transmission is slower in Africa, but faster in the European and American regions.

Discussion of the regional variations in local transmission, morbidity, and mortality of the COVID-19

The late arrival of the virus to Africa in addition to the lower prevalence of confirmatory tests could explain the lower incidence rates in Africa (38). One argument against the lower incidence of testing as a reason for less local transmission is that apart from the number of confirmed cases being low, the number of deaths and thus the CFR were also lower in Africa. Most African countries started to lockdown after $12^{\text {th }}$ March when Africa's first mortality had been recorded (36). The lower CFR rates despite late institution of lockdown measures and the late ban on international travels into African countries suggest that there may be other reasons than late arrival for the low transmission rates and deaths in the African region.

The proximity of Thailand (first SEARO country affected) to China, the earlier importation of the virus than other regions and the consequent earlier awareness and commencement of containment measures together with the likelihood of information sharing with China (where the first case was detected), could be responsible for the similar CFR values observed in Southeast Asian and Western Pacific regions. On the other hand, the highest CFR observed in the eastern Mediterranean region could be as a result of hampered emergency preparation as a result of war, terrorism and the economic downturn from dwindling global oil prices in worst-affected parts of the region like Iran (39). Both Europe and the Americas are highly industrialized regions with well-developed healthcare infrastructure in most of the countries but Europe has higher CFR presently, although the virus was imported earlier into the Americas, before Europe. One major intervention that could have made the difference was an earlier international border closure to high-risk countries by the United States (40), the most populous nation in the Americas, this measure could have prevented multiple international entries from very high-risk countries and limited geometric progression in local transmission rates. This also manifested in the longer intervals from index case to first mortality observed for both the Americas and Western Pacific regions, as similar measures above were used by China to lock down Wuhan, 
isolate the infected and quarantine the sick (3, 8).

\section{Other findings from COVID epidemiological data}

The higher mortality rates observed in the European and Eastern Mediterranean regions could be due to the following reasons which have been earlier recognized by some researchers; a high proportion of aged populations in many of the countries in these two regions, which also agrees with the epidemiological modeling of the disease showing that the elderly are more susceptible to infection and death from the COVID-19 virus $(8,16)$. Death has also been reported more among individuals with co-morbid diseases especially chronic illnesses with defective ACE2 signaling mechanisms, like lung disease, kidney, heart disease, stroke, and diabetes (3, $8,41)$. These diseases are also commoner among the aged, a sort of double tragedy in Europe. This is unlike in Africa, where the population is mostly of younger people with population median age as of 2013, of 18.7 years for the WHO Africa region, compared to 38.6 years for Europe and 23.7 years for the Eastern Mediterranean region (42). This information might be useful for the Americas and the Western Pacific region with population median ages $>30$ years (31.8 years and 36.5 years respectively). Available data also shows that there are more confirmed cases and deaths among males than females (8), higher risk of contact, from higher male employment rates and more outdoor male occupations may explain this. Among females, there is presently no difference in outcomes between COVID-19 infected pregnant and non-pregnant women (3).

Theories for the regional variations in morbidity and mortality of COVID-19; why the disease may have less effect in Africa

Several theories have been proposed for the lower CFR observed in Nigeria and most of the sub-Saharan African nations, apart from some which have been earlier mentioned above.

1. COVID-19 laboratory testing: There were concerns about the few numbers of countries with capacity for testing as at the end of January 2020. The few testing laboratories, the paucity of testing kits, and the lower number tested have also been stated as reasons for the low incidence of COVID-19. As of $10^{\text {th }}$ February, there were only 2 testing laboratories in the African region (38). The use of blood samples has also been blamed for the lower numbers of confirmed positive cases because blood has less sensitivity than to nasal, or oropharyngeal swabs, but the fewer number of deaths (an easily identifiable adverse outcome) suggests that the transmission rate may be lower in Africa.

2. Temperature: The SARS-Cov-2, like other coronaviruses, has been shown to survive in cold and freezing temperatures as low as $20^{\circ} \mathrm{C}$. It has also been demonstrated that the virus is thermo-labile and can be destroyed by temperatures used in normal cooking $\left(\geq 70^{\circ} \mathrm{C}\right)(43)$. It has been postulated that the SARS-Cov-2 virus cannot withstand surfaces with usual atmospheric temperatures in Africa; this appears anecdotal as there are no reports from studies to confirm this yet.

3. Acquired cross-immunity: some authors have reported similar incidence and mortality of the COVID-19 in a belt described as the 'BCG belt' which comprises of countries that still have an active BCG immunization program, this theory has been used to explain the very high fatalities recorded in the European countries of Italy, Spain, and France and the lower mortalities in countries with an active BCG program like Japan and, many countries in Southeast Asia and subSaharan Africa (44). Also, the frequent exposure to malaria and the repeated use of Chloroquine for the treatment of malaria has been thought to produce some immune response, which may protect against viral replication in African hosts, the findings of the effectiveness of Chloroquine and Azithromycin combination for COVID-19 treatment from a French randomized controlled trial has been used to support this theory (45).

4. Acquired cross-immunity from other viral infections; infections with or immunization against other viruses like the picornaviruses (polio, coxsackie, hepatitis, etc.), especially those which confer herd immunity like polio vaccination (poliovirus is yet to be completely eradicated in Africa, with active on-going immunization in most of the subSaharan nations) may provide some immune modulation that may help alter the course of the COVID-19 infection.

5. Acquired cross-immunity from previous similar viral epidemics: The regions which experienced the SARS-Cov and the MERSCov epidemic have been expected to have lower immunity, but the WHO data presented above does not reflect any regional variations in local transmission in favor of regions previously affected by these earlier coronaviruses. 


\section{Effects of COVID-19 in pregnancy and the newborn}

The various changes in the cardiovascular and respiratory systems, hematological and immunological systems occur naturally to help the pregnant woman cope with the pregnancy, tolerate the fetus, and help her prepare for delivery. These changes may, however, worsen especially the effect of any respiratory tract infection and predispose them to complications (46). The COVID-19 is a virus which has a predilection for the airways, causing viral pneumonia in many cases; it is thus expected to potentially increase the risk of adverse outcome for respiratory tract infection in pregnancy.

Within the limits of sparse data on outcomes of the novel COVID-19 in pregnancy; the present reality is that no clear cut evidence supports pregnant women being at increased risk of adverse outcomes than the general adult population (3).

Relatively few cases have been reported of infants confirmed with COVID-19 and they experienced mild illness (3). No evidence of vertical transmission has yet been documented, instead, high amounts of IgM and IgG antibodies were observed in neonates born to COVID-19 positive mothers $(3,41)$. Some researchers have tested amniotic fluid, cord blood and oropharyngeal swabs of neonates born to COVID-19 positive women and all have tested negative $(3,41)$. Also, breast milk samples from COVID-19 infected mothers were found to test negative $(47,48)$.

\section{Conclusion}

Globally, deaths from COVID-19 are less in young people including women and children, but higher in the aged and individuals with chronic illnesses. This pandemic appears to have lower local transmission rates and fatality in Africa, the region with the youngest population median age, and where the virus arrived last. While special efforts should be geared at shielding the elderly and infirm from contracting the infection, preventive measures in pregnant women must allow for access to emergency obstetric care to forestall untoward COVID-19 impounding maternal mortality.

\section{List of Abbreviations}

ACE-2: Angiotensin-Converting Enzyme-2

AFRO: African region

AMRO: Region of the Americas

ARDS: Acute Respiratory Distress Syndrome

BCG: Bacillus Calmette Guerin

CFR: Case Fatality Rate

COVID-19: CoroNaVIrus Disease-19
EURO: European Region

EMRO: Eastern Mediterranean Region

ICU: Intensive Care Unit

LMIC: Low and Middle-Income Countries

MERS-CoV: Middle East Respiratory

Syndrome Coronavirus

RNA: Ribonucleic acid

SARS-CoV: Severe Acute Respiratory

UAE: United Arab Emirates

Syndrome Coronavirus

USA: United States of America

WHO: World Health Organization

\section{Declarations}

\section{Consent for Publication}

The authors hereby transfer all copyright ownership exclusively to the journal, if this work is published by the journal.

\section{Conflicts of Interest}

The author declares that there is no conflict of interest regarding the publication of this manuscript.

\section{Funding}

The author received no research funding.

\section{Acknowledgment}

Sincere thanks to the WHO for regular updates posted to healthcare professionals and the access given to data on cases, deaths, and research on the coronavirus.

\section{References}

1. World Health Organization. Maternal health in Nigeria: generating information for action. Sexual and reproductive health Bulletin. WHO. Geneva; 2020 [cited 2020 Apr 7]. Available from:

https://www.who.int/reproductivehealth/mat ernal-health-nigeria/en/

2. World Health Organization. Speeches by Director General. Coronavirus disease 2019 (COVID-19). Situation Report-71. WHO. Geneva; 2020.

https://doi.org/10.1093/ww/9780199540884 .013 .0161119

3. World Health Organization. Clinical management of severe acute respiratory infection (SARI) when COVID-19 disease is suspected: interim guidance. WHO. Geneva; 2020 [cited 2020 Apr 1] . Available from: https://apps.who.int/iris/handle/10665/3314 46

4. World Health Organization. Coronavirus disease 2019 (COVID-19). Situation Report-75. WHO. Geneva; 2020. [cited 2020 Apr 5]. Available from: 
https://www.who.int/docs/defaultsource/coronaviruse/situationreports/20200404-sitrep-75-covid19.pdf?sfvrsn=99251b2b 2

5. World Health Organization. Health Systems in Africa: Community Perceptions and Perspectives. The Report of a Multi-Country Study. WHO. Geneva; 2020 [cited 2020 Apr 7]. Available from:

https://www.afro.who.int/sites/default/files/2 017-06/english---health systems in africa--2012.pdf

6. Does Nigeria have too many doctors to worry about a 'brain drain'? BBC. COM. News. BBC. United Kingdom; 2020 [cited 2020 Apr 7] Available from: https://www.bbc.com/news/world-africa45473036

7. The Africa Report. How coronavirus and the global oil price war can impact Nigeria. The Africa Report; 2020 [cited 2020 Apr 7]. Available from:

https://www.theafricareport.com/24442/how -coronavirus-and-the-global-oil-price-warcan-impact-nigerial

8. Huang C, Wang Y, Li X, Ren L, Zhao J, Hu $Y$, et al. Clinical features of patients infected with 2019 novel coronavirus in Wuhan, China. Lancet. 2020; 395: 497-506.

https://doi.org/10.1016/S01406736(20)30183-5

9. The World Bank. Year in Review: 2018 in 14 Charts. IBRD, IDA. Washington DC; 2020 [cited 2020 Apr 7]. Available from: https://www.worldbank.org/en/news/feature /2018/12/21/year-in-review-2018-in-14charts

10. Nigeria Demographic and Health Survey. National Population Commission, Nigeria. The DHS Program, ICF, Macro, Rockville, Maryland, USA; 2018 [cited 2020 Apr 7]. Available from:

https://www.dhsprogram.com/pubs/pdf/FR3 59/FR359.pdf

11. National Population Commission, Federal Republic of Nigeria: Final Report on Nigeria Demographic and Health Survey. 2008, Calverton, Maryland, USA: ORC Macro. p. 125-133.

12. Ebuehi OM, Akintujoye IA. Perception and utilization of traditional birth attendants by pregnant women attending primary health care clinics in a rural local government area in Ogun state, Nigeria. Int J Womens Health. 2012; 4:25-34.

https://doi.org/10.2147/ijwh.s23173

13. Peiris JS. Coronaviruses. In: Richman DD, Whitley RJ, Hayden FG, eds. Clinical virology. ASM Press, Washington DC. 2016. 4th edn. P. 1243-1265.
14.Drosten C, Günther S, Preiser W, van der Werf S, Brodt HR, Becker $S$, et al. Identification of a novel coronavirus in patients with severe acute respiratory syndrome. N Engl J Med 2003; 348(20): 1967-76.

15. World Health Organization. Summary of probable SARS cases with onset of illness from 1 November 2002 to 31 July 2003. WHO. Geneva; 2003 [cited 2020 Apr 9]. Available from: https://www.who.int/csr/sars/country/table2 00404 21/en/

16. Team NCPERE. Vital surveillances: the epidemiological characteristics of an outbreak of 2019 novel coronavirus diseases (COVID-19) - China. China CDC Weekly. 2020; 2(8):113-22.

17. Wu Z, McGoogan JM. Characteristics of and important lessons from the coronavirus disease 2019 (COVID-19) outbreak in China: summary of a report of 72314 cases from the Chinese Center for Disease Control and Prevention. JAMA. 2020;323(13):12391242. https://doi.:10.1001/jama.2020.2648

18. Yang X, Yu Y, Xu J, Shu H, Xia J, Liu H et. al. Clinical course and outcomes of critically ill patients with SARS-CoV-2 pneumonia in Wuhan, China: a single-centered, retrospective, observational study. Lancet Respir Med; 2020; S2213-2600(20)30079$5 . \quad$ https://doi:10.1016/S22132600(20)30079-5

19.Zhou F, Yu T, Du R, Fan G, Liu Y, Liu Z et. al. Clinical course and risk factors for mortality of adult inpatients with COVID-19 in Wuhan, China: a retrospective study. Lancet. 2020; S0140-6736(20)30566-3. https://doi.org/10.1016/S01406736(20)30566-3

20.Xu Z, Shi L, Wang Y, Zhang J, Huang L, Zhang $C$, et al. Pathological findings of COVID-19 associated with acute respiratory distress syndrome, Lancet Resp. Med. 2020; S2213-2600(20)30076-X. https://doi.org/10.1016/S22132600(20)30076-X

21.Li X, Geng M, Peng Y, Meng L, Lu S, Molecular immune pathogenesis and diagnosis of COVID-19. J. Pharm. Anal. 2020; [Epub ahead of print]. PMID: 32282863.

https://doi.org/10.1016/j.jpha.2020.03.001

22. World Health Organization. Coronavirus disease 2019 (COVID-19) Situation Report -71. WHO. Geneva; 2020 [cited 2020 Apr 1]. Available from: https://www.who.int/docs/defaultsource/coronaviruse/situation- 
reports/20200331-sitrep-71-covid-

19.pdf?sfvrsn=4360e92b 4

23. World Health Organization. Coronavirus disease 2019 (COVID-19). Situation Report -1.WHO. Geneva; 2020 [cited 2020 Apr 4]. Available from:

https://www.who.int/docs/defaultsource/coronaviruse/situationreports/20200121-sitrep-1-2019ncov.pdf?sfvrsn=20a99c10 4

24. World Health Organization. Coronavirus disease 2019 (COVID-19). Situation Report - 5.WHO. Geneva; 2020[cited 2020 Apr 4]. Available from:

https://www.who.int/docs/defaultsource/coronaviruse/situationreports/20200125-sitrep-5-2019ncov.pdf?sfvrsn=429b143d 8

25. World Health Organization. Coronavirus disease 2019 (COVID-19). Situation Report -3. WHO. Geneva; 2020 [cited 2020 Apr 4]. Available from:

https://www.who.int/docs/defaultsource/coronaviruse/situationreports/20200123-sitrep-3-2019ncov.pdf?sfvrsn=d6d23643 8

26. World Health Organization. Coronavirus disease 2019 (COVID-19). Situation Report -9. WHO. Geneva; 2020 [cited 2020 Apr 4]. Available from:

https://www.who.int/docs/defaultsource/coronaviruse/situationreports/20200123-sitrep-3-2019ncov.pdf?sfvrsn=d6d23643 8

27. World Health Organization. Coronavirus disease 2019 (COVID-19). Situation Report -37. WHO. Geneva; 2020 [cited 2020 Apr 4]. Available from:

https://www.who.int/docs/defaultsource/coronaviruse/situationreports/20200226-sitrep-37-covid19.pdf?sfvrsn=2146841e 2

28. World Health Organization. Coronavirus disease 2019 (COVID-19). Situation Report -39. WHO. Geneva; 2020 [cited 2020 Apr 4]. Available from:

https://www.who.int/docs/defaultsource/coronaviruse/situationreports/20200228-sitrep-39-covid19.pdf?sfvrsn=5bbf3e7d 4

29. Wuhan Municipal Health Commission's briefing on the pneumonia epidemic situation. Wuhan Municipal Health Commision. Hubei. China; 2020 [cited 2020 Apr 5]. Available from: http://wjw.wuhan.gov.cn/front/web/showDet ail/2020011109035

30. World Health Organization. Coronavirus disease 2019 (COVID-19). Situation Report
-13. WHO. Geneva; 2020 [cited 2020 Apr 4]. Available from:

https://www.who.int/docs/defaultsource/coronaviruse/situationreports/20200202-sitrep-13-ncovv3.pdf?sfvrsn $=195 f 40106$

31. World Health Organization. Coronavirus disease 2019 (COVID-19). Situation Report -42. WHO. Geneva; 2020 [cited 2020 Apr 4]. Available from:

https://www.who.int/docs/defaultsource/coronaviruse/situationreports/20200302-sitrep-42-covid19.pdf?sfvrsn=224c1add 2

32. World Health Organization. Coronavirus disease 2019 (COVID-19). Situation Report -27. WHO. Geneva; 2020 [cited 2020 Apr 4]. Available from:

https://www.who.int/docs/defaultsource/coronaviruse/situationreports/20200216-sitrep-27-covid19.pdf?sfvrsn=78c0eb78 4

33. World Health Organization. Coronavirus disease 2019 (COVID-19). Situation Report -43. WHO. Geneva; 2020 [cited 2020 Apr 4]. Available from:

https://www.who.int/docs/defaultsource/coronaviruse/situationreports/20200303-sitrep-43-covid19.pdf?sfvrsn=76e425ed 2

34. World Health Organization. Coronavirus disease 2019 (COVID-19). Situation Report -31. WHO. Geneva; 2020 [cited 2020 Apr 4]. Available from:

https://www.who.int/docs/defaultsource/coronaviruse/situationreports/20200220-sitrep-31-covid19.pdf?sfvrsn=dfd11d24 2

35. World Health Organization. Coronavirus disease 2019 (COVID-19). Situation Report -52. WHO. Geneva; 2020 [cited 2020 Apr 4]. Available from:

https://www.who.int/docs/defaultsource/coronaviruse/situationreports/20200312-sitrep-52-covid19.pdf?sfvrsn=e2bfc9c0 4

36. World Health Organization. Coronavirus disease 2019 (COVID-19). Situation Report -16. WHO. Geneva; 2020 [cited 2020 Apr 4]. Available from:

https://www.who.int/docs/defaultsource/coronaviruse/situationreports/20200205-sitrep-16ncov.pdf?sfvrsn=23af287f 4

37. World Health Organization. Coronavirus disease 2019 (COVID-19). Situation Report -56. WHO. Geneva; 2020 [cited 2020 Apr 4]. Available from:

https://www.who.int/docs/defaultsource/coronaviruse/situation- 
reports/20200316-sitrep-56-covid-

19.pdf?sfvrsn=9fda7db2 6 .

38. Steenhuysen J, Nebehay S. Countries rush to build diagnostic capacity as coronavirus spreads. Reuters; 2020 [cited 2020 Apr 8]. Available from:

https://www.reuters.com/article/us-chinahealth-diagnostics-focus/countries-rush-tobuild-diagnostic-capacity-as-coronavirusspreads-idUSKBN2042DV

39. Iran hit hardest as oil price war, coronavirus cripples nation. Fox News; 2020 [cited 2020 Apr 8]. Available from: https://www.foxnews.com/world/iran-oilprice-war-coronavirus-outbreak

40. Trump's claim that he imposed the first 'China ban'. The Washington Post; 2020 [cited 2020 Apr 8].Available from: https://www.washingtonpost.com/politics/20 20/04/07/trumps-claim-that-he-imposedfirst-china-ban/

41. Schwartz DA. An Analysis of 38 Pregnant Women with COVID-19, their newborn infants, and maternal-fetal transmission of SARS-CoV-2: Maternal Coronavirus Infections and Pregnancy Outcomes. Arch Pathol Lab Med. [Online ahead of print]. https://doi.org/10.5858/arpa.2020-0901-SA.

42. World Health Organization. Global Health Observatory Data Repository (Eastern Mediterranean Region). Population Data by WHO region. WHO. Geneva; 2020 [cited 2020 Apr 8]. Available from:https://apps.who.int/gho/data/view.mai n-emro.POP2020?lang=en

43. World Health Organization. Coronavirus disease 2019 (COVID-19). Situation Report -32. WHO. Geneva; 2020 [cited 2020 Apr 4]. Available from: https://www.who.int/docs/default-

source/coronaviruse/situation-

reports/20200221-sitrep-32-covid-

19.pdf?sfvrsn=4802d089 2

44. Miller $A$, Reandelar MC, Fasciglione $K$, Roumenova V, Li Y, Otazu GH. 2020. Correlation between universal BCG vaccination policy and reduced morbidity and mortality for COVID-19: an epidemiological study. 2020. medRxiv preprint

https://doi.org/10.1101/2020.03.24.200429 37.

45. Gautret $\mathrm{P}$, Lagier JC, Parola P, Hoang VT, Meddeb L, Mailhe $M$ et al. Hydroxychloroquine and Azithromycin as a treatment of COVID-19: results of an openlabel non-randomized clinical trial. Int $\mathrm{J}$ Antimicrob Agents. 2020; 20:105949. [Epub ahead of print]. https://doi.org/10.1016/j.ijantimicag.2020.1 05949 .

46. Rasmussen SA, Jamieson DJ, Uyeki TM. Effects of influenza on pregnant women and infants. Am J Obstet Gynecol; 2012. 207(3 Suppl):S3-S8. https://doi.org/10.1016/j.ajog.2012.06.068

47. Chen H, Guo J, Wang C, Luo F, Yu X, Zhang $W$ et. al. Clinical characteristics and intrauterine vertical transmission potential of COVID-19 infection in nine pregnant women: a retrospective review of medical records. Lancet; 2020; 395(10226):809-15. https://doi.org/10.1016/S01406736(20)30360-3.

48.Zhu H, Wang L, Fang C, Peng S, Zhang L, Chang $G$ et. al. Clinical analysis of 10 neonates born to mothers with 2019-nCoV pneumonia. Transl Pediatr. 2020;9(1):5160. https://doi.10.21037/tp.2020.02.06. 